\title{
Supratip dysplasia
}

INSERM

\section{Source}

INSERM. (1999). Orphanet: an online rare disease and orphan drug data base. Supratip dysplasia. ORPHA:466695

Supratip dysplasia is a rare, congenital, non-syndromic, nose and cavum malformation characterized by the presence of a bulbous, soft tissue hypertrophy located in the middle-to-distal third of the nasal dorsum, in association with deformed, slightly laterallyand caudally-placed nasal alae and a scar-like atrophic skin lesion located at the nasal tip. Respiratory function is not affected. 